Brock, G. and Atkinson, Q. D. (2008). What can examining the psychology of nationalism tell us about our prospects for aiming at the cosmopolitan vision? Ethical Theory and Moral Practice, 11(2): 165-179.

\title{
What can examining the psychology of nationalism tell us about our prospects for aiming at the cosmopolitan vision?
}

\author{
Gillian Brock \\ Philosophy Department, University of Auckland, 507 International Fisher Building, \\ 18 Waterloo Quadrant, Auckland 1000, New Zealand \\ e-mail: g.brock@auckland.ac.nz \\ Q. D. Atkinson \\ Institute of Cognitive and Evolutionary Anthropology, University of Oxford, \\ 64 Banbury Rd, Oxford OX2 6PN, UK
}

1. Motivations for the project

The central idea to being a cosmopolitan is that of being a citizen of the world. As a citizen of the world one is part of a global community of human beings, and as Martha Nussbaum elaborates on this idea, one owes allegiance "to the worldwide community of human beings" (Nussbaum, 1996, 4). Cosmopolitans, more generally, have in common the view that all people have equal moral worth or value, that those people who happen not to belong to our particular group (ethnic, national, or political, say) are not less valuable than those who do (Pogge, 2002). All people have equal moral worth to all others. Both the ideas of equal moral worth and of belonging to a worldwide community of human beings entail that our responsibilities to others do not stop at the borders of state or national groups. Cosmopolitans are opposed to views according to which norms of justice apply properly or primarily only "within bounded groups comprising some subset of the global population" (Scheffler, 1999, 256).

Various cosmopolitans offer several arguments for why one should take up the cosmopolitan stance (Beitz 1979; Caney 2005; Jones 1999; Moellendorf 2002; Nussbaum 1996; Pogge, 2002; Shue, 1980; Singer, 2002; Tan 2004). The following four are commonly invoked considerations. First, that all humans are owed certain things simply by virtue of being human and the asymmetry of current life chances does not adequately reflect our basic entitlements. Second, views about our equality require that, as a matter of distributive justice, we must ensure that all individuals are enabled to enjoy the 
Brock, G. and Atkinson, Q. D. (2008). What can examining the psychology of nationalism tell us about our prospects for aiming at the cosmopolitan vision? Ethical Theory and Moral Practice, 11(2): 165-179.

prospects for decent lives. Third, benefiting from unjust institutional schemes (such as currently dominate the world's economic, political and trade relations) implicates us in them if no reasonable efforts at institutional reform are made. Fourth, global problems (such as environmental, health or security crises) highlight our interdependence and mutual vulnerability. Solving these problems will require much more global co-operation than currently exists, and also require us to rethink traditional notions of sovereignty, governance, reciprocity, and more generally, what we owe one another.

In addition to making several kinds of arguments as to why one ought to adopt cosmopolitanism, many theorists also work on developing views about what must be done in this actual world to instantiate the ideal. Many of their proposals concerning implementation are motivated by the realisation that we need more global co-operation to solve some of the pressing collective problems we face in the areas of threats to health, the environment, security, and well-being more generally. Our global interdependence means that if we are to solve a range of problems we have to tackle these together, rethinking more traditional notions of sovereignty, democracy, and governance. Several cosmopolitans present blueprints for implementing cosmopolitan governance that range from not changing much at all on the ground, simply reforming the United Nations in various directions that better reflect people's equality, to offering bolder plans that would better approximate more global democracy (Falk, 1995; Held, 1995; and Pogge, 2002). David Held has, arguably, done the most to develop these plans offering us realistic, interim, achievable reforms as well as longer-term goals (Held, 1995 and 2004). Held discusses how we might democratize transnational institutions and decision-making. He suggests various mechanisms that could help us approximate the ideal of democracy more closely. These include making greater use of referenda and allocating public funding for deliberative bodies, such as a second chamber of the United Nations only for democratic nations in which representatives would be elected and accountable directly to democratic peoples. This body would initially be introduced to complement the General Assembly of the UN, but with the aim of replacing it in the long run. He also believes we should create regional parliaments and governance structures (in places such as Latin America 
Brock, G. and Atkinson, Q. D. (2008). What can examining the psychology of nationalism tell us about our prospects for aiming at the cosmopolitan vision? Ethical Theory and Moral Practice, 11(2): 165-179.

and Africa) and enhance the role of such bodies where they already exist (for instance, in the case of the European Union). The decisions of these regional bodies could, in time, become recognized as having legitimate force for those regions. Furthermore, we should open up international governmental organizations (such as the World Trade Organisation, International Monetary Fund, and World Bank) to public examination and agenda setting. Such bodies should "be open to public scrutiny (on the basis perhaps of elected supervisory bodies, or functional deliberative fora, representative of the diverse interests in their constituencies), and accountable to regional and global assemblies" (Held, 2004, 112). He would also like to see the establishment of new organizations and mechanisms (where these do not exist or are weak) to address pressing environmental and social affairs, such as global poverty and welfare. This is vital to counterbalance the asymmetry of power currently enjoyed by market-oriented agencies such as the WTO and IMF. One more recommendation we mention here concerns security. He suggests we develop law enforcement and coercive capacity to assist in dealing with serious regional security threats. This could be operationalized "if a proportion of a nation-state's military were permanently seconded to a UN peacemaking force or if international enforcement capacities were increased by creating a permanent independent force recruited directly among individuals who volunteer from all countries, and who could be trained in an international military academy" (Held, 2004, 113).

Opponents of the cosmopolitan project often dismiss these kinds of proposals on the grounds that the cosmopolitan project falls down on a much more basic set of concerns. Frequently the cosmopolitans' proposals are criticised as being unrealistic, not implementable in a world of real people with real emotions, and that we cannot create the necessary motivation for people to want to carry out the cosmopolitan vision (Barber,

For critical discussion and defense of some of these ideas see, for instance: Brock, G. "World Citizenship: David Miller and the New Cosmopolitans," International Journal of Politics and Ethics, 2, Fall (October), 211-224, 2002; Brock, G. "Why the Heldian Model of Cosmopolitan Democracy Retains its Promise Despite Kymlicka's Criticisms," Philosophy in the Contemporary World, 9 (2), 3139, 2002; Brock, G. "The New Nationalisms," The Monist, 82, 367-386, 1999; Brock, G. "Cosmopolitan Democracy and Justice: Held versus Kymlicka," Studies in East European Thought, Special Issue: Nationalism and its Alternatives, 54, 325-347, 2002; Brock, G. "What Do We Owe Conationals and Non-nationals? Why the Liberal Nationalist Account Fails and How We Can Do Better," Journal of Global Ethics, 1, 127-151, 2005; and Brock, G. "Liberal Nationalism versus Cosmopolitanism: Locating the Disputes," Public Affairs Quarterly, 16, 307-327, 2002. 
Brock, G. and Atkinson, Q. D. (2008). What can examining the psychology of nationalism tell us about our prospects for aiming at the cosmopolitan vision? Ethical Theory and Moral Practice, 11(2): 165-179.

1996; Kymlicka, 2001; McConnell, 1996; Miller, 1995; Pinsky, 1996). In particular, some claims made by nationalists (even liberal nationalists) would seem to stand in the way of the project. Many of these claims are rooted in or revolve around assertions about our purported deep human needs, for instance, that we have deep human needs to belong to groups (which are well satisfied by membership in national groups) and favoritism for co-nationals is an inevitable part of satisfying this deep need (Kymlicka, 1989, 1995; Miller, 1995; Tamir, 1993). Other need-based claims include that we have a need for meaning, a need to make sense of our lives, a need for identity, or a need for self-esteem, and the idea is that in all these cases, these deep human needs are well-satisfied by belonging to national groups (Baumgarten, 2000; Glover, 1997; McMahan, 1997; Nielsen, 1999; Tamir, 1993; Wellman, 2000). Once these national groups have formed, some of the dynamics of group membership are such that one can reasonably expect that ingroup solidarity will arise and persist, and members will naturally feel a stronger sense of trust and partiality towards fellow members (Miller, 1995, 2000; Tamir, 1993). It is argued that whenever you have an ingroup there must be an outgroup: it is part of the process of ingroup formation that a certain amount of outgroup hostility will occur (Margalit, 1997). Non members of the group will probably inevitably fare worse than members, but this is all part of the psychological reality that must be taken into account in adequate theorizing.

Our central project in this paper is to examine whether such criticisms are wellfounded, by looking at accounts of the psychology of nationalism. We examine what could be achieved in our world to instantiate the cosmopolitan vision given human realities: both weaknesses and possibilities. Exploring views about the psychology of group identification is thus key to the project. We start off by examining some of the dynamics of group membership that are thought standardly to come into play. We examine studies of "minimal group distinctiveness". As we will see, though commonly invoked, this standard story cannot easily be applied to the case of the psychology of nationalism. 
Brock, G. and Atkinson, Q. D. (2008). What can examining the psychology of nationalism tell us about our prospects for aiming at the cosmopolitan vision? Ethical Theory and Moral Practice, 11(2): 165-179.

To be clear, we realise that nationalists have several kinds of arguments for their position. (Indeed, we critically discuss some of these elsewhere. ${ }^{\text {ii }}$ ) However, nationalists often put significant weight on the force of one line of attack in particular, namely, the apparent psychological evidence that is assumed to go in their favour and undermine the prospects for cosmopolitanism. Our primary objective here is to examine the strength of this purported evidence. The focus of this paper is to examine in detail this allegedly important line of attack against cosmopolitanism.

Before we proceed, a definitional issue requires attention. In this paper we take nationalism to be a sense of identification with a group of people who share a number of characteristics such as common history, language, culture or territory (Searle-White, 2001). Unlike several other definitions of nationalism, we do not assume that nationalism must include any other features, such as, hostility towards non-members or partiality for co-members. We do not assume these are matters of definition, but rather leave these as open questions.

\section{Psychological explanations for Nationalism}

1. Minimal Group Distinctiveness, Realistic Conflict Theory, and the dynamics of group membership

By examining the literature on group dynamics and prejudice, one might initially think that things look pretty bleak for cosmopolitanism. Studies on ethnocentrism ${ }^{\text {iii }}$

\footnotetext{
ii See, for instance: Brock, G. "World Citizenship: David Miller and the New Cosmopolitans," International Journal of Politics and Ethics, 2, Fall (October), 211-224, 2002; Brock, G. "Why the Heldian Model of Cosmopolitan Democracy Retains its Promise Despite Kymlicka's Criticisms," Philosophy in the Contemporary World, 9 (2), 31-39, 2002; Brock, G. "The New Nationalisms," The Monist, 82, 367-386, 1999; Brock, G. "Cosmopolitan Democracy and Justice: Held versus Kymlicka," Studies in East European Thought, Special Issue: Nationalism and its Alternatives, 54, 325-347, 2002; Brock, G. "What Do We Owe Co-nationals and Non-nationals? Why the Liberal Nationalist Account Fails and How We Can Do Better," Journal of Global Ethics, 1, 127-151, 2005; and Brock, G. "Liberal Nationalism versus Cosmopolitanism: Locating the Disputes," Public Affairs Quarterly, 16, 307-327, 2002.

iii 'Ethnocentrism' refers to the perception that one's own group is the standard by which others should be judged, and that this group is somehow superior to other groups (Sumner, 1906).
} 
Brock, G. and Atkinson, Q. D. (2008). What can examining the psychology of nationalism tell us about our prospects for aiming at the cosmopolitan vision? Ethical Theory and Moral Practice, 11(2): 165-179.

and prejudice have revealed that, in general, there is strong "ingroup favoritism": people tend to rate members of their own group as more likeable, intelligent and trustworthy than members of out-groups (Tajfel et al., 1971). Indeed, more worryingly, it does not take much to trigger the phenomenon of ingroup favoritism and its apparent counterpart, hostility to an outgroup ("outgroup derogation"). Numerous studies of "minimal group distinctiveness" have shown that even the assignment of persons to groups on the basis of some arbitrary consideration, such as the result of a coin toss (Billig and Tajfel, 1973) or subjects' apparent preference for an artist (Tajfel et al., 1971), is enough to create ingroup favoritism. It might be thought that nationalism is just an inevitable result of this sort of phenomenon, that is, the result of (perceived or real) differences between national groups.

When groups are in competition for resources, the situation appears to be even worse (Levine and Campbell, 1972). According to Realistic Conflict Theory (RCT; Sherif, 1966), intergroup hostility arises because of actual conflict between groups' interests, especially when there is competition for resources. A number of studies support this hypothesis, probably the most well-known of which are the "Robber's Cave" field experiments (Sherif, 1966). The subjects were boys attending summer camps. They were divided into two groups and intergroup competition was promoted by having the boys engage in competitive games and sports. The competition between groups was found to increase group cohesion and ingroup favoritism, and also created a strong sense of hostility towards outgroup members. It might be thought that RCT can explain nationalism as the result of actual competition between nations for scarce resources.

There are good reasons to go beyond the results that minimal group distinctiveness and RCT yield. Brewer (1999) criticizes the application of minimal distinctiveness results from laboratory experiments to larger groups in the general population. Small effects measured in a controlled culturally sterile laboratory 
Brock, G. and Atkinson, Q. D. (2008). What can examining the psychology of nationalism tell us about our prospects for aiming at the cosmopolitan vision? Ethical Theory and Moral Practice, 11(2): 165-179.

situation involving a small number of people may have limited validity when applied to the real world. Most notably, such experiments ignore the importance of organizational structure of groups in society and the potentially powerful influence of social norms on individual behaviour and beliefs. Brewer $(1999,2001)$ also argues that intergroup bias typically takes the form of ingroup favoritism not outgroup derogation. We discuss these issues in a later section.

What weight can we put on the results RCT yields? Even if RCT explains how intergroup bias can arise in certain cases, it does not explain why bias persists, or why bias arises when there is no conflict between groups. How are we to explain the preference group members show for each other at the level of the nation when there is no competition at issue?

Furthermore, the explanations canvassed so far do not shed much light on the underlying psychological mechanisms that explain nationalism. For instance, how does the mind come to view a collection of individuals as two distinct groups in the first place? What explains ingroup favoritism: is it part of a strategy to maximize personal gain? Does it perhaps reflect a certain amount of altruism that extends to other members of the group but no further? If the latter, what prospects are there for extending the ingroup, or stretching the boundaries of groups? If group boundaries are as fickle as RCT and the minimal group distinctiveness experiments suggest, then it may be relatively easy to redraw the lines. In order to address such questions we need deeper explanations, in particular, we need a psychological mechanism (or mechanisms) to explain the behavior that minimal group distinctiveness and RCT report. We turn to these mechanisms next.

\section{The need for self-esteem}

Social Identity Theory (SIT; Tajfel and Turner, 1979) holds that there are two components to our identities: an individual and a social component. As well as our individual identities, we each have multiple social identities and our thoughts, feelings 
Brock, G. and Atkinson, Q. D. (2008). What can examining the psychology of nationalism tell us about our prospects for aiming at the cosmopolitan vision? Ethical Theory and Moral Practice, 11(2): 165-179.

and behavior are influenced by the identity that is most salient in a particular context. According to Social Identity Theory, individuals affiliate with groups in order to enhance self-esteem: group identification is motivated by the need for selfenhancement (Tajfel and Turner, 1979). If individuals perceive that a group identity will enhance self-esteem, they identify with the group, especially when they suffer economic or social deprivation that diminishes self-esteem. Furthermore, individuals use intergroup bias (such as occurs in the case of nationalism) to satisfy their need for positive self-esteem. The easiest way to build a positive sense of self-esteem and selfworth is to compare ourselves with others perceived to be inferior. So it helps to have plenty of others around to which one can feel superior, and denigrating others helps to create such a comparison group. This is also consistent with the psychodynamic perspective. Outgroups serve a psychological function by allowing us to project negative feelings about ourselves onto a group of others, thus increasing our selfesteem (Searle-White, 2001).

There is, however, evidence that the need for self-enhancement does not underly ingroup identification. For instance, individuals show strong identification with disadvantaged and low-status groups, and individuals with high self-esteem often show greater ingroup identification than those whose self-esteem is low (Crocker and Schwartz, 1985). Gilbert, Fiske, and Lindzey $(1997,564)$ state that "overall, research in this area supports the idea that positive ingroup evaluation and collective selfesteem is the product of group identification rather than its cause". iv Lemyre and Smith's (1985) study of the relationship between categorization, intergroup bias and self-esteem found that, in fact, categorization lowers self-esteem and intergroup bias acts only to restore this drop. Indeed, Blank (2003), in a study of East and West

iv Moreover, recent evidence makes clear that in contrast to the view that people simply passively adopt whatever views others hold of them into their self-concept, evidence from the last two decades shows that people actually engage in several strategies to protect or enhance their self-esteem when others regard their social groups negatively. So, for instance, individuals can detach their self-esteem from others' evaluations, or disengage their sense of self from the outcomes in particular domains and contexts (Gilbert, Fiske, and Lindzey, 1998, 529). Stigma does not necessarily affect psychological well-being. The stigmatized are not especially dissatisfied with their lives, in fact most of them claim to be pretty happy (Gilbert, Fiske, and Lindzey, 1998, 531). 
Brock, G. and Atkinson, Q. D. (2008). What can examining the psychology of nationalism tell us about our prospects for aiming at the cosmopolitan vision? Ethical Theory and Moral Practice, 11(2): 165-179.

German national identity, found that general positive or negative self-esteem was only weakly related to national identification. On an individual level, intergroup bias and discrimination can be damaging to self-esteem (Allport, 1954).

Hence, while there is some evidence for an association between intergroup bias and self-esteem, the hypothetical causal relationships are not well understood, and studies such as Lemyre and Smith (1985) and Blank (2003) suggest that, regardless, nationalism is not a particularly effective self-esteem boost. Indeed, for a good summary of how complex the relationship between nationalism and self-esteem can be see Spinner-Halev and Theiss-Morse (2003). If the assumption is that the need for self-esteem can straightforwardly support a case for liberal nationalism, matters are not so clear. In section II we suggest some cosmopolitan alternatives.

3. The need for identity and the need for belonging

Research on the relationship between the strength of ingroup identification and ingroup status indicates that motives other than desire to increase self-esteem are at play when we select or maintain social identities. Brewer offers a compelling alternative motivational account, namely, "optimal distinctiveness theory".

The theory postulates that human beings have two powerful social motives: a need for inclusion that motivates assimilation of the self into large, impersonal collectives, and an opposing need for differentiation that is satisfied by distinguishing the self from others. As opposing motives, the two needs hold each other in check. When a person feels isolated or detached from any larger social collective, the drive for inclusion is aroused; on the other hand, immersion in an excessively large or undefined social collective activates the search for differentiation and distinctiveness (Brewer, 2001, 21-22) 
Brock, G. and Atkinson, Q. D. (2008). What can examining the psychology of nationalism tell us about our prospects for aiming at the cosmopolitan vision? Ethical Theory and Moral Practice, 11(2): 165-179.

According to optimal distinctiveness theory, social identification is the product of the search for the optimal mix for an individual between inclusion and differentiation needs, rather than simply a consequence of searching to fulfill a need for belonging, or a need for self-esteem, or the result of searching to fulfill any other one need.

Intergroup bias is not a necessary product of group identification, according to Brewer. She challenges the dominant assumptions made initially by Sumner (1906) that ingroup attachment and outgroup hostility are essentially part of the same phenomenon. Sumner's view comprised of four separable claims:

1. The Social Categorization Principle: Human social groups divide into (mutually exclusive) ingroups and outgroups.

2. The Ingroup Positivity Principle: members of groups positively value their ingroups and value maintaining co-operative relations with other ingroup members.

3. The Intergroup Comparison Principle: Comparison with outgroups in which ingroups fare better enhances ingroup positivity.

4. The Outgroup Hostility Principle: Relations between ingroups and outgroups are characterized by hostility.

Sumner maintained that these four theses universally characterized intergroup relations, but more recent psychological research challenges this view (Brewer, 1979; Turner, 1978; Mummendey et al, 1992; Feshbach, 1994; Kostermand and Feshbach, 1989). In particular, Brewer maintains that the four theses are distinct and that each element provides a necessary condition for the next step in a progression. However, while the first two principles, principles 1 and 2, are highly entrenched, Brewer argues that principles 3 and 4 certainly are not (Brewer, 2001).

Unlike Social Identity Theory, Optimal Distinctiveness Theory does not rely on the fairly questionable idea of the search for self-esteem as the motivation for group identification. Each individual's identification with a nation (or some other group), is the product of both forces pulling towards identification and forces pulling away from it, and these can vary from context to context. It is no surprise then that 
Brock, G. and Atkinson, Q. D. (2008). What can examining the psychology of nationalism tell us about our prospects for aiming at the cosmopolitan vision? Ethical Theory and Moral Practice, 11(2): 165-179.

we might all end up at various points on a scale of identification and that various factors can influence and alter identification. This will turn out to be good news for cosmopolitans, as we discuss.

Much research now corroborates Brewer's views that ingroup identification can occur without out-group derogation. More specifically, national identification need not be associated with negative sentiment towards non-nationals. Heaven et al. (1985) conducted research in Australia and South Africa and found no significant relationship between ingroup identification and outgroup derogation. Mummendy, Klink and Brown (2001) also found support for the independence of national identification and outgroup derogation. In their analyses of intergroup bias between East African ethnic groups Brewer and Campbell (1976) found that, whilst individuals did evaluate their own group more positively on personality dimensions such as trustworthiness, this was not correlated with perceived social distance towards outgroups or outgroup hostility.

\section{The need for meaning}

Some defenders of nationalism have argued that nationalism satisfies various existential human needs, such as, a need for meaning, a need for an overall worldview to structure one's choices and so to reduce the uncertainty that would otherwise plague us, or a need for a sense of stability and permanence. Many authors have argued that we all need some framework, system of values or goals which helps us make sense of our lives (Fromm, 1973; Bruner, 1990). Nationalism can help provide this framework, a system of values and more generally, a sense of meaning in life.

According to Abrams and Hogg (1988), it is the need for reducing uncertainty that is the primary motivation for social identification. Festinger $(1950,1954)$ argues that people need a sense of validity for their beliefs, and this is gained by "social reality testing": beliefs are accepted as appropriate when they are shared by similar 
Brock, G. and Atkinson, Q. D. (2008). What can examining the psychology of nationalism tell us about our prospects for aiming at the cosmopolitan vision? Ethical Theory and Moral Practice, 11(2): 165-179.

others. Conformity to reference groups' views provides stability and confidence in one's own perceptions and choices.

According to Terror Management Theory (Solomon, Greenberg and Pyszczynski, 1991), fear of our individual mortality and the possibility of tragic events can create an overwhelming sense of anxiety. This anxiety can motivate us to replace our ephemeral subjective reality with an enduring cultural worldview, such as a national identity, that imposes order and meaning on what can be perceived as a random and meaningless world. Individuals then view threats to this adopted worldview as threats to their own self-esteem. People identify at the level of the nation because this is perceived to be an established and enduring social construct on which they can build their self-esteem. Their identification is contingent on this particular social construct being available and enduring.

While a deep human need for an enduring cultural worldview may partly explain why we identify at the level of the nation state and why this results in bias, Terror Management Theory does not imply either that nationalism is the only currently available option to satisfy this need, nor that it is the best option to meet this need. In fact, as we discuss further along, it suggests that other enduring cultural worldviews may be equally effective, if not more so. (Similar arguments apply to the other existential needs identified above.)

National identities may perform a certain function in our current world for some people, but this function was performed by other identities in the past. When salvation was held as the key desirable aim in life, religious identities were very important to people, as was the case during the Middle Ages in Europe. When class identity was the way to gain a sense of respect and self-worth, class identity was generally people's more salient social identity. The international system privileges nations and their self-determination as a way to gain international standing, so it should not be at all surprising that national identity can assume the kind of importance it currently does for people. One could predict that the less important the role of the nation is in our lives, the less significant any psychological effects will be. 
Brock, G. and Atkinson, Q. D. (2008). What can examining the psychology of nationalism tell us about our prospects for aiming at the cosmopolitan vision? Ethical Theory and Moral Practice, 11(2): 165-179.

If the importance of national identity to people derives its significance in large part because of the way the world is structured -- in particular, the importance we give nation-states in decision-making and general control over people's lives -- then at least one of the features that promotes nationalism is subject to our control. We can choose to organise the world differently so that national identity does not have the kind of status it currently does.

5. Biological needs and evolutionary arguments

Some defenders of nationalism may concede that the form of bias for groups (or ethnocentrism) that is nationalism may be a more contingent matter that is socially constructed and to some extent socially alterable. However, they may insist, there is some underlying biological need -- or reality rooted in evolutionary theory -- that is not easy to ignore. The roots of ethnocentrism have primal origins and it is here that we will find support for bias to fellow group members.

Evolutionary arguments in particular are thought to constitute another potential justification for nationalism. According to defenders of such arguments, as a result of natural selection, it may be that humans have a biological drive or need to discriminate, which confers fitness benefits. By identifying the selective pressures that may have produced such a drive, we can determine whether it is likely to be particularly important at a national level. As an example, we take Brewer's (1999) evolutionary explanation for intergroup bias (which is consistent with Optimal Distinctiveness Theory). She argues that group living represents the fundamental survival strategy characteristic of humans. As a species, cooperation and social learning have replaced strength and instinct as basic adaptations. "The result is that, as a species, human beings are characterized by obligatory interdependence. For long-term survival, we must be willing to rely on others for information, aid, and shared resources, and we must be willing to give information and aid and to share resources with others" (Brewer, 1999, 433). But providing these resources and 
Brock, G. and Atkinson, Q. D. (2008). What can examining the psychology of nationalism tell us about our prospects for aiming at the cosmopolitan vision? Ethical Theory and Moral Practice, 11(2): 165-179.

assistance must be balanced with the likely benefit of receiving resources and assistance in return. Indiscriminate trust is not an effective survival strategy: "altruism must be contingent on the probability that others will cooperate as well" (Brewer, 1999, 433). Establishing group boundaries through social categorization and differentiation provide a mechanism for achieving cooperative interdependence and its attendant benefits, but without excessive costs. The mutual trust becomes depersonalized. Expectations of cooperation and benefit promote positive feelings towards other group members, thus explaining ingroup favoritism.

According to this view, intergroup bias is the result of an interaction between an assimilation instinct and a differentiation instinct and these motivations are themselves the result of hundreds of thousands of years of selection for individuals who were able to maximize the survival advantage of cooperative interdependence. However, this kind of ultimate evolutionary explanation does nothing to bolster the claim that nationalism is particularly suited to satisfying some deep human needs.

Brewer notes that trust and cooperation seem to be most effectively realised in small distinctive groups: indeed, the explanatory story she offers relies on this. However, if the assimilation and differentiation instincts were selected to limit the extent of intertribal cooperation, how is this to explain the ethnocentrism we are supposed to show towards fellow nationals, who might number in the several hundred millions? Can we really see our fellow nationals as being in relationships of cooperative interdependence and trust in a way analogous to the small group that forms the centre of Brewer's explanation? One possibility is that the instincts are misapplied to the case of the nation -- though the assimilation and differentiation instincts applied at the level of the tribe in the past with increased fitness benefits, the application at the level of the nation does not have the same results.

Alternatively, one might argue that the unit of cooperation in the contemporary world is the nation-state, so the same phenomena that applied to the small band in the past, in today's environment are simply transferred to the unit of cooperation in our contemporary world, namely, the nation-state. Of course, if we find 
Brock, G. and Atkinson, Q. D. (2008). What can examining the psychology of nationalism tell us about our prospects for aiming at the cosmopolitan vision? Ethical Theory and Moral Practice, 11(2): 165-179.

this reasoning plausible, could we not try to extend it? Arguably, the unit of cooperation is far greater than the nation-state, especially since globalization has rendered more plausible the idea that there is significant global co-operation. If the instincts can transfer from the tribe to hundreds of millions of people, why not further still? One objection to such an extension might be that linguistic or cultural barriers provide an upper limit to the extent of in-group identification. However, the strength of nationalism in countries such as the USA, India, and Singapore, all with considerable cultural and/or linguistic diversity, suggest that even these barriers can be overcome.

Arguments appealing to innate human drives can imply a degree of genetic determinism that is unrealistic. It is becoming increasingly accepted that the relationship between genotype and phenotype is rarely simple and almost never fixed. Far from coding for specific optimal behaviours, behavioural geneticists now realize that genes are just one part of a complex context dependent and constrained developmental unfolding that makes us the way we are. As a result, appeals to some underlying human nature that constrains our society independent of culture and learning, must be viewed with scepticism.

Finally, natural selection is still often misunderstood as a Machiavellian struggle for existence in which only the most ruthlessly self-interested organisms survive - a view often associated with Richard Dawkins' (1976) selfish-gene theory, which reduces evolution to a competitive struggle between genes. Under this conception of evolution, altruistic group behaviour can occur, but only if it is expected to result in some sort of reciprocity between individuals - dubbed 'reciprocal altruism' (Trivers, 1971). Hamilton's (1964) kin selection theory allows some degree of altruism without reciprocity, but only towards closest kin who are likely to share many of the same genes. This may not seem to bode well for the cosmopolitan vision. However, humans may be unique in that much of the behavioural variation we see between groups is culturally, rather than genetically determined. Cultural differences, unlike genetic differences, can be preserved even in 
Brock, G. and Atkinson, Q. D. (2008). What can examining the psychology of nationalism tell us about our prospects for aiming at the cosmopolitan vision? Ethical Theory and Moral Practice, 11(2): 165-179.

the face of migration between groups. This means that selection can also operate at the level of the group, allowing selection for traits such as altruism and cooperation that benefit the group. Sober and Wilson $(1994,585)$ argue that cooperative behaviour is an important aspect of human nature: -

"Humans can facultatively span the full range from self-interested individuals to 'organs' of group-level 'organisms.' Human behavior not only reflects the balance between levels of selection but it can also alter the balance through the construction of social structures that have the effect of reducing fitness differences within groups, concentrating natural selection (and functional organization) at the group level."

Recent experimental findings using 'public goods' games confirm that humans are willing to cooperate in ways that cannot be explained in terms of selfish motives of reciprocal altruism or kin selection (see Fehr and Fischbacher [2003] for a recent review of this evidence). The more interesting question may then be, not why we show the intergroup bias that we do, but why we show such a need to cooperate and how we can promote this need. As we will see below, there are good reasons to think that we can build on the cooperative side of our nature.

\section{II: Is Cosmopolitanism psychologically viable?}

Amongst the most vociferous critics of cosmopolitanism are those who claim that the view simply flies in the face of the realities of how we are constituted and our psychological constraints (Barber, 1996; McConnell, 1996; Pinsky, 1996). We cannot ever become the kinds of people cosmopolitans urge us to be because of our psychological limitations. In this section we examine the plausibility of this sort of claim and show what prospects cosmopolitanism might reasonably have, given any psychological constraints that there might be on us, but also reasonable psychological possibilities.

The Common Ingroup Identity model (Gaertner et al., 1993) maintains that an overarching superordinate identity can reduce intergroup bias and prejudice. The 
Brock, G. and Atkinson, Q. D. (2008). What can examining the psychology of nationalism tell us about our prospects for aiming at the cosmopolitan vision? Ethical Theory and Moral Practice, 11(2): 165-179.

theory was first presented by Sherif (1954) who maintained that whilst competition reinforces group boundaries, intergroup cooperation induces changes in identity from a competitive "us versus them" conception to a cooperative "we". There is a large body of literature supporting the idea that cooperation between groups reduces intergroup bias (see, for example, Alport, 1954; Sherif, 1966; Slavin, 1985, Gaertner et al., 1999) and this reduction in bias is assisted by changes in conceptions of group membership (Gaertner et al., 1990, 1994, 1996) or having a strong common goal (Brewer and Brown, 1998, 582). (Even the well-cited Robber's Cave experiments that showed how easily group hostility is triggered under competitive conditions also showed that a super-ordinate identity can also easily be erected under the right conditions (Sherif, 1966).)

Allport (1954) suggested that intergroup cooperation involved two components -- shared process (interaction) and shared outcomes (common fate). "Interaction" is defined as doing things with individuals from an outgroup. "Common fate" refers to any shared outcomes between groups, for instance, a shared reward for completing a task. Gaertner et al. (1999) found that both factors operate independently to reduce intergroup bias. The reduction in intergroup bias was found to be greatest among those subjects who perceived the group relationship as a superordinate identity made up of distinct subgroup identities.

Deschamps and Brown (1983) found that the reduction in intergroup bias was greatest when there was a clear division of labor between subgroups in completing the cooperative projects. The nature of the cooperative task can affect how successfully intergroup bias is reduced. In experiments run by Gaertner (1999), it was found that when cooperating subgroups were asked to complete an essay task for a shared reward, in the set of conditions under which one group worked on text and the other graphics, the cooperation reduced intergroup bias more than when both groups were asked to contribute to the essay as a whole (when both contributed to text and graphics). 
Brock, G. and Atkinson, Q. D. (2008). What can examining the psychology of nationalism tell us about our prospects for aiming at the cosmopolitan vision? Ethical Theory and Moral Practice, 11(2): 165-179.

So we see there is evidence that intergroup cooperation can engender social recategorization -- an overarching sense of common identity between groups can be created -- and this can lead to reduction in intergroup bias. The effect can vary with a number of factors, including the nature of the cooperative task and, it seems, the extent to which individuals may still maintain their subgroup identities within any overarching or superordinate identity.

To the extent that we can apply these results to the level of the nation, it would seem that certain types of interaction (particularly co-operation) between nations and certain kinds of common fates, should reduce national bias. At the moment, the chances of achieving this seem to be greatest where cooperation allows a superordinate identity to be established without compromising national identity. This is encouraging news for cosmopolitans who believe we need transitional strategies: we can maintain something of the familiar -- retain people's comfort zone, so to speak -- while working to extend that comfort zone at the same time.

In addition to creating a superordinate identity, it may also be possible to dilute the importance of national identity through more complex identities. Societies differentiated along a single categorization give rise more easily to outgroup derogation by promoting social comparison and perceptions of conflict of interests (Brewer, 2000). However, complex societies with multiple, overlapping categories of differentation may be more stable and tolerant, and the levels of intergroup bias may be significantly reduced (Ensari and Miller, 2001; Urban and Miller, 1998).

There are other interesting factors that can reduce ethnocentricism. Jetten, Spears and Manstead (1996) have shown that in allocating rewards, people are generally fair towards an outgroup if a group norm of fairness has been established, otherwise they are biased in favor of their ingroup. Duckitt (2001) looked at individual differences in levels of intergroup bias. He found that levels of intergroup bias in individuals are related to cultural ideological attitudes and worldviews. Levels of bias also correlate with social values such as individualism versus collectivism. Triandis (1995) found that ingroup-outgroup distinctions appear to be more salient in 
Brock, G. and Atkinson, Q. D. (2008). What can examining the psychology of nationalism tell us about our prospects for aiming at the cosmopolitan vision? Ethical Theory and Moral Practice, 11(2): 165-179.

collectivist societies than in individualistic societies. Once again, this is encouraging news for cosmopolitans - intergroup bias appears to be malleable and culturally dependent, and not simply an innate drive.

What factors can we expect to promote cooperation between large-scale groups? As we mentioned above, Fehr and Fischbacher (2003) review experimental evidence showing that humans have a strong drive to behave altruistically in a group. In 'public goods' games, played for small but real monetary rewards, subjects will contribute $40-60 \%$ of their entitlement even when there is no possibility of future interaction, and hence reciprocation (Dawes, 1980). The amount contributed is influenced by the amount individuals expect others to contribute (Fischbacher et al., 2001). If the game is repeated anonymously, contributions decrease to much lower levels (Isaac and Walker, 1988), however a number of factors have been shown to produce sustained cooperative behaviour. Unselfish cooperation can be encouraged without requiring external coercive force by providing opportunities to punish defectors (e.g. Heinrich et al., 2001), reward cooperators (e.g. Fehr et al., 1993) and build a reputation through repeated interaction (e.g. Fehr et al., 2002). These findings reinforce the importance of the social environment in determining cooperative behaviour and suggest that, in order to promote the global cooperation advocated by cosmopolitanism, we must provide institutional mechanisms that allow defectors to be punished, cooperators to be rewarded, and for those with power to be held accountable.

Finally, what prospects are there for cosmopolitanism to meet some of the needs nationalists make so much of? There is some evidence to suggest that cooperative or altruistic behavior increases self-esteem and a more general sense of well-being (Kagan and Knight, 1979; Muhlbauer, 1984; Simmons, Schimmel \& Butterworth, 1993; Williams, Haber, Weaver \& Feeman, 1998), though whether or not this effect is greater than potential increases in self-esteem and well-being sometimes induced by nationalism requires further research. 
Brock, G. and Atkinson, Q. D. (2008). What can examining the psychology of nationalism tell us about our prospects for aiming at the cosmopolitan vision? Ethical Theory and Moral Practice, 11(2): 165-179.

The need for meaning can, of course, be variously satisfied. Brewster-Smith (1992) argues that even if there is a deep human need for large-scale group identity and direction, this could be satisfied in more constructive ways than through nationalism, ethnocentricism, and war. Having some sense of purpose often drives people to engage in conflict and war, and it is following up on such ideas that he suggests we take up a "war to preserve nature". This sort of undertaking can provide people with meaning and an enduring worldview just as effectively as nationalism can. Arbuthnot (1977) found that those with pro-environmental attitudes and behaviour are less likely to hold conservative views such as nationalistic commitment, consistent with the idea that pro-environmental attitudes may replace nationalism as a source of meaning. Indeed, we already see some of this sort of passionate commitment today amongst various environmental groups and members of Green Parties throughout the world. The sense of empowerment involvement in such activities provides may act to raise self-esteem as well (e.g. Meinhold \& Malkus, 2005). More research is needed to investigate this relationship. More generally, we hope that more research into the needs that cosmopolitanism could satisfy will now be undertaken, given that the charge of cosmopolitanism's psychological infeasibilty has been addressed.

\section{Conclusions}

In this essay we examined the psychological grounds claimed to support the importance of nationalism to our well-being. We found that the alleged human needs that nationalism is said to satisfy are: (i) either more complex than initially one might think or (ii) do not necessarily provide very strong grounds for the theses advocated by nationalists or (iii) can be well met in alternate ways than through national identification and bias. Moreover, commitment to cosmopolitanism is not antithetical to meeting these needs: rather, more cosmopolitan worldviews can do quite well in meeting the needs of interest, though more research should be done on this topic. 
Brock, G. and Atkinson, Q. D. (2008). What can examining the psychology of nationalism tell us about our prospects for aiming at the cosmopolitan vision? Ethical Theory and Moral Practice, 11(2): 165-179.

Furthermore, we saw that since nationalism is a fluid and socially constructed phenomenon, quite open to the influence of other factors, the current evidence suggests that central aspects of cosmopolitanism are quite feasible and realistic. Nationalism is no more an innate or necessary part of the human psyche than is a sense of global community.

\section{$\underline{\text { References }}$}

Abrams, D. \& Hogg, M. A. (1988). Comments on the motivational status of self esteem in social identity and intergroup discrimination. European Journal of Social Psychology, 18, 317-334.

Allport, G.W. (1954). The nature of prejudice. Reading, MA: Addison-Wesley. Arbuthnot, J. (1977). The roles of attitudinal and personality variables in the prediction of environmental behaviour and knowledge. Environment and Behaviour, $9(2), 217-232$.

Barber, B. (1996). Constitutional Faith. In J. Cohen (ed.) For Love of Country: Debating the Limits of Patriotism. Boston: Beacon Press, 30-36.

Baumgarten (2000). Zionism, Nationalism and Morality. In N. Miscevic (ed.) Nationalism and Ethnic Conflict: Philosophical Perspectives. Chicago: Open Court, 75-98.

Beitz, C. (1979). Political Theory and International Relations. Princeton, NJ: Princeton University Press.

Blank, T. (2003).Determinants of National Identity in East and West Germany: An Empirical Comparison of Theories on the significance of Authoritarianism, Anomie, and General Self-Esteem. Political Psychology, 24, 259-288.

Billig, M. and Tajfel, H. (1973). Social categorization and similarity in intergroup behaviour. European Journal of Social Psychology. Vol. 3(1), 27-52.

Brewer, M.B. (1979). Ingroup bias in the minimal intergroup situation: A cognitive motivational analysis. Psychological Bulletin, 86, 307-324.

Brewer, M. B. (1999). The Psychology of Prejudice: ingroup love or outgroup hate? Journal of Social Issues 55:429-44.

\footnotetext{
${ }^{\mathrm{v}}$ We are grateful for the useful comments made by two anonymous reviewers for this journal.
} 
Brock, G. and Atkinson, Q. D. (2008). What can examining the psychology of nationalism tell us about our prospects for aiming at the cosmopolitan vision? Ethical Theory and Moral Practice, 11(2): 165-179.

Brewer, M. B. (2001). Ingroup identification and intergroup conflict: When does ingroup love become outgroup hate? In R. D. Ashmore and L. Jussim (Eds). Social identity, intergroup conflict, and conflict reduction. Rutgers series on self and social identity; vol. 3. (pp. 17-41). London: Oxford University Press.

Brewer, M. and Brown, R. (1998). Intergroup Relations. In D. Gilbert, S. Fiske, G. Lindzey (eds.) The Handbook of Social Psychology, volume 2, chapter 29. New York: McGraw-Hill.

Brewer, M. B. and Campbell, D. T. (1976). Ethnocentrism and intergroup attitudes: East African evidence. Beverly Hills, CA: Sage.

Brewster Smith, M. (1992). Nationalism, Ethnocentrism, and the New World Order. Journal of Humanistic Psychology, 32 (4), 76-91.

Brock, G. (1999). "The New Nationalisms," The Monist, 82, 367-386.

Brock, G. (2002a)."Cosmopolitan Democracy and Justice: Held versus Kymlicka," Studies in East European Thought, Special Issue: Nationalism and its Alternatives, 54, 325-347.

Brock, G. (2002b). "Liberal Nationalism versus Cosmopolitanism: Locating the Disputes," Public Affairs Quarterly, 16, 307-327.

Brock, G. (2002c). "Why the Heldian Model of Cosmopolitan Democracy Retains its Promise Despite Kymlicka's Criticisms," Philosophy in the Contemporary World, 9 (2), 31 39.

Brock, G. (2002d). "World Citizenship: David Miller and the New Cosmopolitans," International Journal of Politics and Ethics, 2, Fall (October), 211-224.

Brock, G. "What Do We Owe Co-nationals and Non-nationals? Why the Liberal Nationalist Account Fails and How We Can Do Better," Journal of Global Ethics, 1, 127-151, 2005

Bruner, Jerome. (1990). Acts of meaning. Cambridge, MA: Harvard University Press.

Caney, Simon (2005) Justice Beyond Borders: A Global Political Theory. Oxford: Oxford University Press.

Crocker, J. and Schwartz, 1. (1985). Prejudice and ingroup favoritism in a minimal intergroup situation: Effects of self-esteern. Personality and Social Psychology Bulletin, $11,379-86$.

Darwin, C. (1859). The origin of species by means of natural selection. Oxford: Oxford University Press.

Dawes, R. M. (1980) Social dilemmas. Annu. Rev. Psychol. 31, 169-193.

Dawkins, R. (1976). The Selfish Gene. Oxford: Oxford University Press.

Deschamps, J-C. \& Brown, R. (1983) Superordinate goal and intergroup conflict.

British Journal of Social Psychology, 22, 189-195. 
Brock, G. and Atkinson, Q. D. (2008). What can examining the psychology of nationalism tell us about our prospects for aiming at the cosmopolitan vision? Ethical Theory and Moral Practice, 11(2): 165-179.

Ensari, N., \& Miller, N. (1998). Effect of affective reactions by the outgroup on preferences for cross categorization discussion partners. Journal of Personality and Social Psychology. 75:1503-27.

Falk, Richard (1995). On Humane Governance: Toward a New Global Politics. Cambridge: Polity Press.

Fehr, E., Fischbacher, U. \& Gächter, S. (2002) Strong reciprocity, human cooperation, and the enforcement of social norms. Hum. Nat. 13, 1-25.

Fehr, E., \& Fischbacher, U. (2003) The nature of human altruism. Nature, 425, 785791.

Fehr, E., \& Gächter, S. (2002) Altruistic punishment in humans. Nature, 415, 137 140.

Fehr, E., Kirchsteiger, G. \& Riedl, A. (1993) Does fairness prevent market clearing? An experimental investigation. Q.J. Econ. 108, 437-459.

Festinger, L. (1950). Informal social communication. Psychological Review, 57, 271282.

Festinger, L. (1954). A Theory of Social Comparison Processes. Human Relations, 7 , 117-140.

Fischbacher, U., Gächter, S. \& Fehr, E. (2001) Are people conditionally cooperative? Evidence from a public goods experiment. Econ. Lett. 71, 397-404.

Fleshbach, S. (1994). Nationalism, patriotism and aggression: A clarification of functional differences. In L. Huesmann (Ed), Aggressive behaviour: Current perspectives (pp. 275-291). New York: Plenum.

Fromm, E. (1973) The Anatomy of Human Destructiveness. New York: Henry Holt \& Company.

Gaertner, S.L., Dovidio, J.F., Anastasio, P.A., Bachman, B.A., \& Rust, M.C. (1993). The common ingroup identity model: Recategorization and the reduction of intergroup bias. In W. Stroebe \& M. Hewstone (Eds.), European review of social psychology (Vol. 14, pp. 1-26). Chichester: Wiley.

Gaertner, S.L., Rust, M.C., Dovidio, J.F., Bachman, B.A., \& Anastasio, P.A. (1994). The contact hypothesis: The role of a common ingroup identity of reducing intergroup bias. Small Group Research, 25, 224-229.

Gaertner, S.L., Dovidio, J.F., \& Bachman, B.A. (1996). Revisiting the contact hypothesis: The induction of a common ingroup identity. International Journal of Intercultural Relations, 20, 271-290.

Gaertner, S.L., Dovidio, J.F., Rust, M.C., Nier, J.A., Banker, B.S., Ward, C.M., Mottola, G.R., \& Houlette, M. (1999). Reducing intergroup bias: Elements of intergroup cooperation. Journal of Personality and Social Psychology, 76, 388-402. 
Brock, G. and Atkinson, Q. D. (2008). What can examining the psychology of nationalism tell us about our prospects for aiming at the cosmopolitan vision? Ethical Theory and Moral Practice, 11(2): 165-179.

Gilbert, D.T., Fiske, S.T., \& Lindzey, G. (eds.)(1997). The Handbook of Social Psychology, $\left(4^{\text {th }}\right.$ edn). New York: McGraw-Hill

Glover, J. (1997). Nations, Identity, and Conflict. In R. McKim and J. McMahan (eds.) The Morality of Nationalism. New York: Oxford University Press.

Gould, S. J. \& Lewontin, R. (1979), The Spandrels of San Marco and the Panglossian Paradigm. Proceedings of the Royal Socociety of London B 205:581-598

Hamilton, W. D. (1964). The genetical evolution of social behaviour. Journal of Theoretical Biology, 7: 1-52.

Heaven, P. C. L., Rajab, D. \& Ray, J. J. (1985). Patriotism and the Disutility of the Ethnocentrism Concept. The Journal of Social Psychology, 125(2), 181-185.

Henrich, J. et al. (2001) In search of Homo economicus: behavioral experiments in 15 small-scale societies. Am. Econ. Rev. 91, 73-78.

Held, D (1995). Democracy and the Global Order: From the Modern State to Global Governance. Stanford: Stanford University Press.

Held, D. (2004). Global Covenant: The Social Democratic Alternative to the Washington Consensus. Cambridge: Polity.

Isaac, R. M. \& Walker, J. M. (1988) Group-size effects in public-goods provisionthe voluntary contributions mechanism. Q. J. Econ. 103, 179-199.

Jetten, J., Spears, R., \& Manstead, A. S. R. (1996). Intergroup norms and intergroup discrimination: distinctive self-categorization and social identity effects. Journal of Personality and Social Psychology, 71, 1222-1233.

Kagan, S., \& Knight, G. P. (1979) Cooperation-competition and self-esteem: A case of cultural relativism. Journal of Cross-Cultural Psychology. Vol 10(4), 457-467.

Kosterman, R., \& Fleshbach, S. (1989). Toward a measure of patriotic nationalistic attitudes. Political Psychology, 10, 257-274.

Kymlicka, W. (1989). Liberalism, Community and Culture. Oxford: Oxford University Press.

Kymlicka, W. (1995). Multicultural Citizenship. Oxford: Oxford University Press.

Kymlicka, W. (2001). Politics in the Vernacular. Oxford: Oxford University Press.

Lemyre, L. and Smith, P. M. (1985). Intergroup discrimination and self-esteem in the minimal group paradigm. Journal of Personality and Social Psychology. 49:660-70.

Le Vine, R. A. \& Campbell, D. T. (1972) Ethnocentrism: Theories of conflict, ethnic attitudes and group behaviour. New York, John Wiley \& Sons. 
Brock, G. and Atkinson, Q. D. (2008). What can examining the psychology of nationalism tell us about our prospects for aiming at the cosmopolitan vision? Ethical Theory and Moral Practice, 11(2): 165-179.

Margalit, A. (1997). The Moral Psychology of Nationalism. In R. McKim and J. McMahan (eds.) The Morality of Nationalism. New York: Oxford University Press, 74-87.

McConnell, M. (1996). Don't Neglect the Little Platoons. In J. Cohen (ed.) For Love of Country: Debating the Limits of Patriotism. Boston: Beacon Press, 78-84.

McMahan, J. (1997).The Limits of National Partiality. In R. McKim and J. McMahan (eds.) The Morality of Nationalism. New York: Oxford University Press, 107-138.

Meinhold, J. L. \& Malkus, A. J. (2005). Adolescent Environmental Behaviours: Can Knowledge, Attitudes and Self-Efficacy Make a Difference? Environment and Behaviour. 37(4), 511-532.

Miller, David (1995). On Nationality. Oxford: Oxford University Press.

Miller, David (2000). Citizenship and National Identity. Cambridge: Polity.

Moellendorf, D. (2002) Cosmopolitan Justice. Boulder, CO: Westview Press.

Mummendey, A., Simon, B., Dietze, C., Grunert, M., Haeger, G., Kessler, S., Lettgen, S., \& Schaferhoff, S. (1992). Categorization is not enough: Intergroup discrimination in negative outcome allocations. Journal of Experimental Social Psychology, 28, 125144.

Mummendey, A, Klink, A., \& Brown, R. (2001). Nationalism and patriotism:

National identifcation and out-group rejection. British Journal of Social Psychology, 40, 159-172

Nielsen, K. (1999). Cosmopolitan Nationalism. The Monist, 82, 446-468.

Nussbaum, M. (1996) Patriotism and Cosmopolitanism. In Joshua Cohen (ed.) For Love of Country: Debating the Limits of Patriotism. Boston: Beacon Press.

Pinsky, R (1996). Eros Against Esperanto. In J. Cohen (ed.) For Love of Country: Debating the Limits of Patriotism. Boston: Beacon Press, 85-90.

Pogge, T. (2002) World Poverty and Human Rights. Cambridge: Polity Press.

Scheffler, S. (1999) Conceptions of Cosmopolitanism. Utilitas 11, 255-76.

Searle-White, J. (2001). The Psychology of Nationalism. New York: Palgrave/St. Martin's Press.

Sherif, M. (1966). In common predicament: Social psychology of intergroup conflict and cooperation. Boston: Houghton-Mufflin.

Sherif, M., Harvey, O. J., White, B. J., Hood, W. R. \& Sherif, C. (1954). Experimental study of positive and negative intergroup attitudes between experimentally produced groups: Robbers Cave Experiment. Norman: University of Oklahoma Press. 
Brock, G. and Atkinson, Q. D. (2008). What can examining the psychology of nationalism tell us about our prospects for aiming at the cosmopolitan vision? Ethical Theory and Moral Practice, 11(2): 165-179.

Shue, H. (1980) Basic Rights: Subsistence, Affluence, and U.S. Foreign Policy. Princeton, NJ: Princeton University Press.

Simmons, R. G., Schimmel, M., \& Butterworth, V. A. (1993) The self-image of unrelated bone marrow donors. Journal of Health \& Social Behavior. Vol 34(4), 285301 .

Singer, Peter (2002). One World: The Ethics of Globalization. New Haven and London: Yale University Press.

Slavin, R.E. (1985). Cooperative learning: Applying contact theory in desegregated schools. Journal of Social Issues, 41(3), 45-62.

Sober, E., \& Wilson, D. S. (1994). Reintroducing group selection to the human behavioral sciences. Behavioral and Brain Sciences 17 (4): 585-654.

Solomon, S., Greenberg, J., \& Pyszczynski, T. (1991). A terror management theory of social behavior: The psychological functions of self-esteem and cultural worldviews. In M. E. P. Zanna (Ed.), Advances in experimental social psychology (Vol. 24, pp. 93-159). San Diego, CA: Academic Press.

Spinner-Halev and Elizabeth Theiss-Morse (2003). National Identity and SelfEsteem. Perspectives on Politics. 1(3), 515-532.

Sumner, W. G. (1906). Folkways. New York: Ginn

Tamir, Y. (1993). Liberal Nationalism. Princeton, NJ: Princeton University Press.

Tan, Kok-Chor (2004). Justice Without Borders: Cosmopolitanism, Nationalism, and Patriotism. Cambridge, Cambridge University Press.

Tajfel, H., Flament, C., Billig, M. and Bundy, R.F. (1971). Social categorization and intergroup behaviour. European Journal of Psychology, 1, 149-78.

Tajfel, H \& Turner, J. C. (1979) An integrative theory of intergroup conflict. In W.G. Austin and S. Worchel (eds), The Social Psychology of Intergroup Relations (pp. 3347). Monterey, CA: Brooks/Cole.

Trivers, R.L. (1971). The evolution of reciprocal altruism. Quarterly Review of Biology, 46, 35-57.

Tuner, J. C. (1978). Social categorization and social discrimination in the minimal group paradigm. In Tajfel, H. (ed), Differentiation Between Social Groups (pp. 101140). London: Academic Press.

Urban, L. M., \& Miller, N. (1998). A theoretical analysis of cross-categorization effects: A meta-analysis. Journal of Personality and Social Psychology, 74, 894-908. 
Brock, G. and Atkinson, Q. D. (2008). What can examining the psychology of nationalism tell us about our prospects for aiming at the cosmopolitan vision? Ethical Theory and Moral Practice, 11(2): 165-179.

Wellman, C. (2000). On Liberalism's Ambivalence regarding Nationalisn. In N. Miscevic (ed.) Nationalism and Ethnic Conflict: Philosophical Perspectives. Chicago: Open Court, 131-151.

Williams, A. L., Haber, D., Weaver, G. D., \& Freeman, J. L. (1998) Altruistic activity: Does it make a difference in the senior center? Activities, Adaptation \& Aging. Vol 22(4), 31-39. 